\title{
THE EFFECTS ECONOMIC USAGE OF STANDARDIZATION OF BUFFALO MILK COMPARED WITH NON - STANDARDIZED FOR PRODUCTION OF FRESH MOZZARELLA CHEESE
}

\author{
Dr.Sc.Shurki Maxhuni, Prof.Assis. ${ }^{1}$, \\ ${ }^{1}$ University “Ukshin Hoti” 20000 Prizren Kosova Europe
}

\begin{abstract}
Cheese is one of the first and most popular manufactured food products. What perhaps started out as an accidental curdling of milk has been further defined into cheese making. Over several thousand years, cheese making has advanced from an art to near science. Cheese varieties have proliferated to suit varied conditions and requirements, especially during the last decade or so.

Actually, new cheeses are often formulated when mistakes happen, so there well may be truth in the tale. This study is done to research the examinations for production of mozzarella cheese, after research and analyses of physical-chemical peculiar feature of milk. We have followed the processes from drying of cheese until preparing it for market, physicalchemical peculiar feature. We carried out three experiments for each milk-kind. For every experiment, we took three patterns and analyzed. Production of this sort of cheese, the application of producing technology and the supply of Kosova's trade market with mozzarella cheese is the objective of this presentation work research.
\end{abstract}

Keywords: Buffalo, Milk, coagulum, cheese, whey, mozzarella.

\section{Council for Innovative Research}

Peer Review Research Publishing System

\section{Journal: Journal of Advances in Chemistry}

Vol. 12 , No. 3

editor@cirjac.com

www.cirjac.com 


\section{INTRODUCTION}

Milk is the only food for mammals, the baby in the first period to give milk containing lifetime. Material energy and building materials needed for the baby's growth. Contains antibodies that protect the baby from infections mammal. (1).

There are two distinct types of milk consumption: a natural source of nutrition for all infant mammals and a food product for humans of all ages that is derived from other animals

Few people are aware that raw milk is actually used as a medicine in the early last century. That's right. Milk directly from breasts was used as medicine to treat, and often cure some serious chronic diseases. From the time of Hippocrates until just after World War II, this "white blood" nourished and has recovered millions of people and cures. (5).

Buffalo milk is a totally natural product that can be consumed like any other milk. Participants in tasting trials prefer buffalo milk when compared to cow's, goat's and artificially manufactured milks because it tastes smoother and is more pleasing to the

palate.

Buffalo milk is very white, significantly less in cholesterol and higher in calcium than cow's, sheep's or goat's milk. In addition to the significant cholesterol and calcium benefits buffalo milk is also a rich source of iron, phosphorous, vitamin $\mathrm{A}$ and protein. Although buffalo milk lacks the yellow pigment, buffalo convert carotene in their diet to vitamin $A$. Buffalo milk is totally free from additives and chemicals used to produce non dairy milk such as soya and rice milks. (12). Buffalo milk contains high levels of the natural antioxidant tocopherol. Peroxidate activity, i.e. levels of oxygen, is normally 2 to 4 times that of cow's Cow`s milk allergy (CMA) is a growing concern for many people. Buffalo milk does not create the same distress and can be tolerated by many CMA sufferers. Buffalo milk has high milk solids, ideal for cheese production and other dairy products. Buffao milk produces the best yogurt that sets naturally without the addition of other ingredients.

Worldwide water buffalo are recognized as a genetically pure species with no cases of mad cow disease or any other transmissible encephalopathies that are found in many species of animals and humans. (12).

Cheese is one of the first and most popular manufactured food products. What perhaps started out as an accidental curdling of milk has been further defined into cheese making. Over several thousand years, cheese making has advanced from an art to near science. Cheese varieties have proliferated to suit varied conditions and requirements, especially during the last decade or so. It is estimated that more than 2000 varieties exist, and the list may be growing. (4).

Buffalo milk makes the best mozzarella. The smooth texture and richness converts into a truly wonderful range of award winning products in many countries.

Please note that we do not have public sales and that all of our milk goes to Natural Pastures Cheese Company to be made into delicious mozzarella di bufala.

58\% more calcium than cow's milk, 40\% more protein than cow's milk, 43\% less cholesterol than cow's milk. (12).

Legend has it that mozzarella was first made when cheese curds accidentally fell into a pail of hot water in a cheese factory near Naples and soon thereafter the first pizza was made! Actually, new cheeses are often formulated when mistakes happen, so there well may be truth in the tale. This study is done to research the examinations for production of mozzarella cheese, after research and analyses of physical-chemical peculiar feature of milk.

In Italy, recently legislation has been introduced to restrict use of term "Mozzarella" only to those products exclusively made from buffalo milk.

Cheese production has three steps: curd formation, curd treatment and curd ripening.

1. Curd important product of fermentative lactic acid bacteria.

2. Curd treatment consists of condensing and squeezing to form dense, hard curd.

It is then molded into the desired shape, salted and mixed with different types of secondary micro flora.

3. Secondary micro flora ripens the cheese and will determine the final texture and aroma of each type of cheese. Most buffalo milk mozzarella sold here is imported from Italy and SouthAmerica.

Mozzarella can be smoked, either in a smoking chamber with intense smoke or by "painting" with a liquid smoke. The curds can be mixed with fresh herbs or chili peppers before forming to flavor the mozzarella. The possibilities and variations are endless. The perish ability of fresh mozzarella varies according to packaging. Vacuum sealing extends the shelf life dramatically. (7\& $9 \& 10 \& 11$ ).

Work Material -Milk For the production of Mozzarella Cheese we have used milk of the following breeds: autochthon Bufallo's in the dairy of the region of Fushë Kosova, in milk industry "Bylmeti". We carried out three experiments for each milk-kind. For every experiment, we took three patterns and analyzed the physical-chemical. The calculation was appraised statistically. We have followed the processes from drying of cheese until preparing it for market, physicalchemical peculiar feature.

We carried out three experiments for each milk-kind. For every experiment, we took three patterns and analyzed the physical - chemical parameters. 
The calculation was appraised statistically. In fact, the best area to produce Mozzarella cheese Buffalo's non-standardized milk.

Work methods IT'S used fresh milk to produce cheeps of mozzarella-unpasteurized cows, buffalo's and goat's with these parameters. For physical-chemical peculiar feature of milk and mozzarella samples were used these methods:

1. For definition of $\mathrm{pH}$ value were used the ph-meter ISOLAB pH -111,

2. Soxhelt-Henkels method were used to define sour taste,

3. For Physical - chemical is utilized LACTOSCAN - D -90,

4. For definition of Nitrogen $(\mathrm{N})$ were used the Kelda's method,

5. For definition of fat percentage \% were use the method of Gerber,

6. for definition of dry matters until drying up of constant mass,

7. Dry quantity of mass without fat has been done in calculated way,

8. Percentage of fat at dry mass has been done in calculated way,

9. Water quantity has been done in calculated way,

10. For definition of saline's $(\mathrm{NaCl})$,

11. Ash\%, (IDF Standard 17 A, 1972).

12. (IDF Standard 17 A, 1972). (8)

Table.1. Physico chemical analisys from buffalo milk non standardezed

\begin{tabular}{|l|l|}
\hline pH & $\mathbf{6 . 6 5}$ \\
\hline${ }^{\circ} \mathrm{SH}$ & $7.0^{\circ} \mathrm{SH}$ \\
\hline Temp Samlle & $16^{\circ} \mathrm{C}$ \\
\hline Fat \% & 7.32 \\
\hline SNF \% & 9.50 \\
\hline Density & 1.03097 \\
\hline Proteine \% & 3.79 \\
\hline Lactose \% & 4.92 \\
\hline Added Water \% & $\mathbf{0 . 0 0}$ \\
\hline Solids \% & $\mathbf{0 . 7 6}$ \\
\hline Freezing Point & $-0.606{ }^{\circ} \mathrm{C}$ \\
\hline Conduc. mS/cm & 4.58 \\
\hline
\end{tabular}

Table.2. Physico chemical analisys from buffalos

Milk standardezed

\begin{tabular}{|l|l|}
\hline pH & 6.42 \\
\hline${ }^{\circ}$ SH & $7.13^{\circ} \mathrm{SH}$ \\
\hline Temp Samlle & $17^{\circ} \mathrm{C}$ \\
\hline Fat \% & 3.16 \\
\hline SNF \% & 9.50 \\
\hline Density & 1.02919 \\
\hline Mate. Sec. \% & 10.11 \\
\hline Added Water \% & $\mathbf{0 . 0 0}$ \\
\hline Solids \% & $\mathbf{0 . 7 5}$ \\
\hline Freezing Point & $-0.596^{0} \mathrm{C}$ \\
\hline Conduc. mS/cm & 4.49 \\
\hline
\end{tabular}


Diagram for production for mozzarella cheese

\section{Fresh milk}

$\underset{\text { Ptsteurized milk }}{\stackrel{\text { Sampling }}{\longrightarrow}} 72^{\circ} \mathrm{C} / 15 \mathrm{sec}$.

$\underset{\text { Milk cooling } 36^{\circ} \mathrm{C} \longrightarrow}{\stackrel{\text { Sampling }}{\longrightarrow}}$

$\longleftarrow$ (Milk) culture castaway 4gr/100I milk (Firma CHR-Ansen-Tipe of culter FRC-75 Bacterie Mezofile 70\% Lactobacillus Bulgaricus 50 U(Junit)

Milk and 30\% Bac.Thermophylus(Lactococcus(Streptoccocus)

Thermophylus), Milk pH=6.4

After 15 minutes

During incubation 50 min

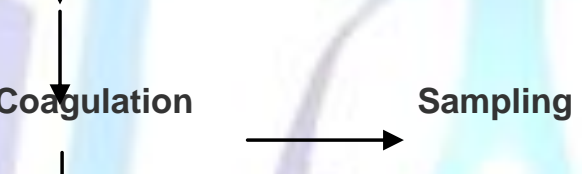

$\downarrow$

Extraction of $w$

Grain exsiccation of coagulum $15 \mathrm{~min}, \mathrm{t}^{\circ} 42^{\circ} \mathrm{C}$

chagulum exudation

Clledderization of curds $-\mathrm{t}^{\circ} 20-24^{\circ} \mathrm{C}, \mathrm{pH}=5.0$

Delicatessen (Sallamura $18 \% \mathrm{NaCl}$ )

Moldiness (formimi) of cheese

Chese packaging

Chaese preservation $\quad(2 \& 3 \& 6)$. 
Table.3.Percentage of Buffalo Cheese produced from standardized milk with $3.2 \%$ of fat

\begin{tabular}{|l|l|}
\hline $\mathbf{p H}$ & 4.95 \\
\hline${ }^{\circ} \mathrm{SH}$ & 50.66 \\
\hline Fat \% & 19.36 \\
\hline Materie such \% & 68.53 \\
\hline General N \% & 2.17 \\
\hline $\begin{array}{l}\text { General proteine } \\
\%\end{array}$ & 39.37 \\
\hline Solids (NaCl) \% & 5.03 \\
\hline SNF \% & 29.81 \\
\hline$\%$ Fat in SNF* & 10.41 \\
\hline Water \% & 31.47 \\
\hline
\end{tabular}

Table.4. Percentage of Buffalo Cheese produced from non standardized milk 30 days

\begin{tabular}{|l|l|}
\hline $\mathrm{pH}$ & 6.41 \\
\hline${ }^{\circ} \mathrm{SH}$ & 27.13 \\
\hline Fat \% & 24.48 \\
\hline Materie such \% & 57.62 \\
\hline General N \% & 2.99 \\
\hline $\begin{array}{l}\text { General proteine } \\
\%\end{array}$ & 29.08 \\
\hline Ash \% & 2.21 \\
\hline Solids (NaCl) \% & 1.74 \\
\hline SNF \% & 33.47 \\
\hline \% Fat in SNF ${ }^{*}$ & 41.90 \\
\hline Water \% & 42.39 \\
\hline
\end{tabular}

*SNF $($ Solids - not - fat $)=$ proteins, lactose, minerals, acids, enzymes, vitamins

\section{Photo.1.}

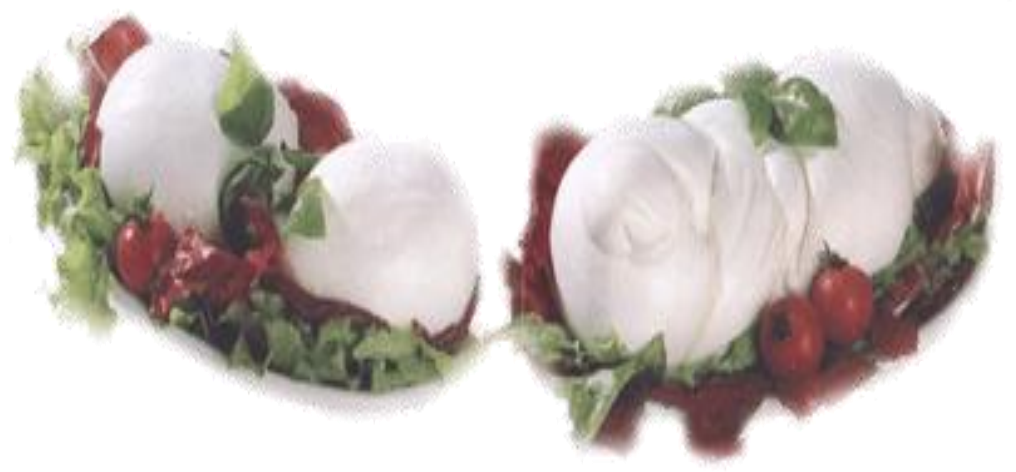

Fresh finished Buffalo's Mozzarella. 


\section{Results and Discusion}

Buffalo milk is commercially more viable than cow, goats and sheep's milk for the manufacture of fat-based and SNFbased milk products, such as butter, ghee and milk powders because of its lower water content and higher fat content. Most significantly, the lower cholesterol value should make it more popular in the health conscious market. By the virtue of greater opacity of casein micelles, coupled with higher levels of colloidal proteins, calcium and phosphorus, buffalo milk is more densely white and has superior whitening properties as compared to cow milk, sheep's and goat's. Therefore, unlike the cow milk (which is pale-creamish yellow in color) and goat's milk fat (which is golden yellow in color), buffalo milk is distinctively whiter. UHT-processed buffalo milk and cream are intrinsically whiter and more viscous than their cow and goat's milk counterparts, because buffalo milk in version of greater levels of calcium and phosphorus into the colloidal form. Buffalo milk is, therefore, more aptly suitable for the production of tea and coffee whiteners than cow milk. Higher innate levels of proteins and fat render buffalo milk a more economical alternative to cow milk for the production of casein, caseinates, whey protein concentrates and a wide range of the fat-rich dairy products.

Cheese made from buffalo milk displays typical body and textural characteristics. More specifically, where chewing and stringing properties are specially desired as in the case of Mozzarella cheese, buffalo milk is technologically preferable over another's milk. In Italy, recently legislation has been introduced to restrict use of term "Mozzarella" only to those products exclusively made from buffalo milk (without admixture with another's milk). Certain traditional cheese varieties, such as pannier in India or pickled cheeses from the Middle-East countries, are best made from buffalo milk.

Buffalo, a fresh, stringy textured cheese with porcelain-white color; it has an extremely thin rind and delicate taste. When cut, it produces a white watery fluid with the aroma of milk enzymes. Apart from its typical round shape, it is also produced in small bite-sized shapes and plaits.

Unlike cow's milk there is no need to homogenize goat's milk.

\section{Conclusion}

\section{The main factor of the economic aspect for the manufacture of mozzarella cheese is the standardization of milk for cheese production with $3.2 \%$ fat.}

Based on exploratory data for production of Mozzarella cheese from un-standardized milk from buffalo's milk we can conclude that:

Fresh milk mast is in the standard with number of microorganisms.

- For the maturity of the curd coagulant the $\mathrm{pH}$ must have the value $5.0-5.2$.

- Color in buffalo's milk is pure white lacks the yellow pigment carotene, precursor for vitamin A, and it's whiteness is frequently used to differentiate it from cow's and goat's milk in the market. Despite the absence of carotene, the vitamin A content in buffalo milk is almost as high as that of cow's and goat's milk. Buffalo prefer to graze a shorter sward to cattle and goat's, nearer to that for sheep, but in cow's and goat's milk the color is creamy.

- The smooth creamy texture of buffalo milk makes it ideal for many types of dairy product. The high levels of solids make processing very much more cost effective when compared to cows and goat's milk. Color of milk is a blend of individual effects produced by:

- Colloidal calcium casein ate/phosphate particles and dispersed/emulsified fat globules, both of which scatter light.

- Carotene (to some extent xanthophylls), which imparts a yellowish color.

The greater intake of green feed, results in deeper yellow color of cow milk.

- Larger fat globules and higher fat percentage also results in increased intensity of yellow color. Upon heating whiteness increases due to increased reflection of light by coagulate. Skim milk has a bluish and whey a greenish yellow color (due to presence of riboflavin), riboflavin (vitamin $\mathrm{B}_{2}$ ) and potassium.

- $\quad$ Fat percentage differentiation in between the non-standardized and standardized milk is big.

- The Fat in buffalo's milk non standardized is $7.32 \%$ and by standardized is $3.16 \%$.

- $3.16 \%$ fat $=100 \%$;

- $7.32 \%-3.16 \%=4.16 \%$ i.e. $=133 \%$ of fat is more invested to produced mozzarella.

2.

For the maturity of the curd coagulant the $\mathrm{pH}$ must have the value 5.0.

- $\quad$ Cheese made from buffalo milk displays typical body and textural characteristics.

- More specifically, where chewing and stringing properties are specially desired as in the case of Mozzarella cheese.

- $\quad$ Buffalo milk is technologically preferable over cows and goats milk. 
- Buffalo, a fresh, stringy textured cheese with porcelain-white color.

- It has an extremely thin rind and delicate taste.

- In general stocking rates for buffalo can be $10-20 \%$ higher than for cattle and goats.

- The temperature must be raised with $2^{0} \mathrm{C}$ more in order to fully ensure the pasteurization of the curd coagulum.

- $\quad$ Though the results of this particular examination are quite good.

- Buffalos cheese is Pure white (color), with Smooth texture Sweet test.

- Though the results of this particular examination are quite good, we would recommend a temperature raise of $2^{\circ} \mathrm{C}$, from $85^{\circ} \mathrm{C}$ to $87^{\circ} \mathrm{C}$ for a $2-3$ minutes period of the pasteurization of the curd coagulant.

- With non standardized milk $7.32 \%$ of fat, we have had produced cheese with $24.48 \%$ fat.

- With standardized milk $3.16 \%$ of fat, we have had produced cheese with $19.36 \%$ of fat.

- Difference between the cheese is: $24.48 \%-19.36 \%=5.12 \%$ of fat

So:3.

- i.e. $19.36 \%=100 \%$

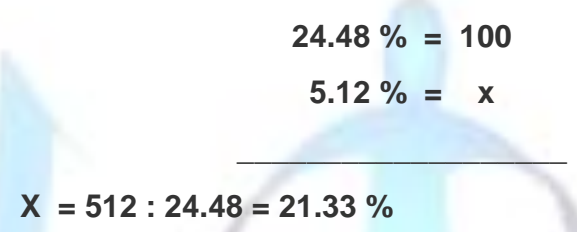

- $\quad 133 \%$ of fat we have more invested to produced cheese, and we have had produced cheese with 21.33 more fat i.e. $133-21.33=111.67 \%$

- We have had lose of fat: $111.67 \% / k g$.

As is un economically to produced cheese with non standardized milk.

- Because, we lose $111.67 \% / \mathrm{kg}$ of fat, to produced $1 \mathrm{~kg}$ of cheese mozzarella.

\section{Literature:}

1. Dr.Sc.Shukri Maxhuni, Row milk, Publisher: LAP LAMBERT Academic Publishing, Novembrey 5, 2013.

2. Dr.Sc.Shukri Maxhuni, Possibility of obtaining of the cheese:

Mozzarella Cheese produced from cows buffalo and goats milk.

Publisher: LAP Lambert Academic Publishing, 19 November 2012.

3. Dr.Sc.Shuri Maxhuni, Impact Of Types Of Milk In Production Cheese Kashkaval

Publisher: LAP LAMBERT Academic Publishing, May 22, 2013.

4. Cheese Rheology and Texture, Gunasekaran Sundaram, M.Mehmet Ak. P.cm. ISBN 1-58716-02-8 (alk.paper), I.Ak.M. Mehmet. II. Title.

Library of Congress Card Nuber 2002034861, Printed in the United States of America $1234567890 @ 2003$ by CRC Press LLC.

5. Dairy processing handbook, Tetra Pak processing Systems AB, S-221 86, 1995. Lund, Sweden.

6. Giuseppe, R., Manuale di technologia casearia, Copyright by “Edagricole”, 1987, Bologna.

7. info@buffalomilk.co.uk43. India Diry.Com/Backgrund Information/Buffalo Milk Vs Cow Milk.

8. IDF Standard 17 A, 1972.

9. Mozzarella Company, 2944 Elm Street, Dallas Texas.

10. Mozzarella di Bufala.org ,Italian version Copyright 2006.

11. Olson, N..F. and Bogenrief. 1995. Functionality of Mozzarella and Cheddar cheese, in Proc. Ath Cheese Sump., T.M. Logan, P.F. Fox, and P. Ross, Eds., pp 15-23. Cork, Ireland.

12. FAIRBURN Water Buffalo. 